\title{
KÜLÖNLEGES BÁNÁSMÓD LÓ-ASSZISZTÁLT FOGLALKOZÁSOKON
}

\author{
Szerző: \\ Schéder Veronika \\ Debreceni Egyetem
}

\author{
Lektorok: \\ Pongrácz László \\ Nyugat-Magyarországi Egyetem \\ Imre Angéla \\ Eötvös Loránd Tudományegyetem \\ Szabó Edina \\ Debreceni Egyetem \\ Szilágyi Barnabás \\ Debreceni Egyetem
}

Szerző e-mail címe:

veronika.scheder@gmail.com

Schéder Veronika (2015): Különleges bánásmód ló-asszisztált foglalkozásokon. Különleges Bánásmód, I. évf. 2015/1. szám, 79-89. DOI 10.18458/KB.2015.1.79

\begin{abstract}
Absztrakt
A Nemzeti Lovas Programban meghatározott feladatokról szóló, 1061/2012 (III. 12.) számú kormányhatározat értelmében 2013 szeptemberétöl - a megemelkedett testnevelési óraszám terhére - Magyarországon minden 3., 4. és 5. osztályos általános iskolás tanuló számára választható tantárgy lehetne a lovaglás. Jelen tanulmány elsősorban egy átfogó ismertetést kíván nyújtani arról, hogy a lovakkal való foglalkozásoknak milyen formái léteznek, s melyek közülük azok, amelyek olyan speciális többlettartalommal, hozadékokkal rendelkeznek, hogy különleges bánásmóddá válva beiktathatók a gyermekeket oktató-nevelö-fejlesztö pedagógusok vagy egyéb szakemberek munkájába. A módszertan bemutatását esetismertetésekkel illusztráljuk.
\end{abstract}

Kulcsszavak: lovaglás, különleges bánásmód, fejlesztés, lovasterápia

Diszciplína: gyógypedagógia

\begin{abstract}
SPECIAL TREATMENT IN HORSE ASSISTED EXERCISE

According to decision No. 1061/2012 (III.12), the Hungarian Goverment is dedicated to National Equestian Programme. Riding has been an optional subject in frame of the everyday physical education for all schoolchild in 3-4-5 classes in Hungary since September 2013. The present study gives an overview of different types of horse activities focusing on approaches that are extremly suitable for teachers, trainers, theraptists and other specialists in the course
\end{abstract}


of educational, pedagogical and developemental improvement of children. The presentation of methodology is complemented by case studies.

Keywords: riding, special treatment, development, horse-therapy

Discipline: special education

A Nemzeti Lovas Programban meghatározott feladatokról szóló, 1061/2012 (III. 12.) számú kormányhatározat értelmében 2013 szeptemberétől - a megemelkedett testnevelési óraszám terhére - Magyarországon minden 3., 4. és 5. osztályos általános iskolás tanuló számára választható tantárgy lehetne a lovaglás. E program megvalósítása azonban láthatólag nem zökkenőmentes, leginkább a megfelelő infrastrukturális és személyi feltételek hiányosságai miatt. Az országos szintű kezdeményezés azonban ráirányítja a figyelmet arra, hogy kezdjük felismerni a lovaglás, a lóval való foglalkozások gyermekeink testi-lelki-szellemi fejlődésére gyakorolt jótékony hatásait. Iskolai kereteken kívül is egyre többen választják a lovaglástanulást szabadidős tevékenységként vagy sportolási céllal. A lovak világából ráadásul a különleges bánásmódot igénylő gyermekek sincsenek kizárva. Hazánkban 2000 óta képeznek lovasterapeutákat, akik országszerte egyre több helyen elérhetőek, és igen hatékony segítséget tudnak jelenteni kiegészítő terápiás munkájukkal a gyógypedagógiai, mozgás- és pszichés fejlesztésekben.

Kiindulásképp érdemes a címben szereplő „ló-asszisztált” kifejezést pontosítani, azaz: mit tekintünk ló-asszisztált foglalkozásnak? A jelen tanulmány ló-asszisztált foglalkozásnak tekint minden olyan időtöltést, amely egy vagy több ló társaságában történik, egy vagy több személy vezetése (különféle jellegü oktató-/fejlesztő munkája, felügyelete) mellett. A foglalkozásokat szabadidős, sport- vagy fejlesztő céllal veszik igénybe a résztvevők. A sportszerü keretek között megvalósuló lovas időtöltések között megkülönböztetjük egymástól a ló-, illetőleg a lovassportokat. Egy lósport esetében a lovak versenyeznek egymással az ember segítségével, a lovassportokban azonban a lovasok mérik össze tudásukat lovaik társaságában (Bodó és Hecker, 2013; Pongrácz, 2006). E tanulmány a kettő közül csak utóbbival érintkezik. A továbbiakban röviden bemutatjuk a lovak legjellemzőbb viselkedési formáit, ezek oki hátterét, valamint a ló és ember kapcsolatának történelmi alakulását, napjainkra jellemző viszonyait. Definiáljuk a ló-asszisztált foglalkozásokat, majd szűkebb értelemben foglalkozunk azokkal a lehetőségekkel, amelyek fontos (és innovatív) adalékokat szolgáltathatnak a különleges bánásmód módszertanához.

\section{A lovak világa}

A mai ló (Equus) ősei kb. 3 millió évvel ezelőtt Amerikából indultak el és vándoroltak át Európába is, benépesítve az egész világot. Az ember környezetében fellelhető állatok sorában az elsők között történt meg a háziasításuk. Bár az ősember kezdetben élelemként tekintett rájuk, hamarosan felfedezte fizikai teherbíró képességüket: előbb teherhordó hátaslóként, majd igavonó erejük kihasználásával fogta be őket a közös munkákba. Különféle régészeti leletek tanúságai szerint i. e. kb. 4000 évvel ezelőtt vehette kezdetét ez a fajta kapcsolat az 
ember és a ló között (Novotni, 2007). Szekér elé először i. e. 1800-750 között, a bronzkor idején fogták, lovaglásra kb. i. e. 1000 óta használjuk a lovakat (Hartje, 2009). Kiegészítették tehát az ember erejét, gyorsaságuknak köszönhetően lehetővé tették a távolságok áthidalását. A közlekedésben, hadászatban, mezőgazdaságban sokáig felbecsülhetetlen társaink voltak. De a lovakkal való versenyzés különböző módjai is szinte egyidősek a ló és az ember kapcsolatával - történelmi dokumentumokból ismertek az ókori görögök kocsiversenyei, a nomád népek lovas játékai (Novotni, 2007). A lovaglásnak az emberi szervezetre gyakorolt jótékony hatását ennél későbbi korokban fedezték csak fel. Bár ismertek feljegyzések arról, hogy a lovaglást már az ókorban is alkalmazta Hippokratész gyógykezelési célzattal az ún. gimnasztika részeként (a gyaloglás és a futás mellett), mégis, az első tudatos tudományos lépést a lovaglás gyógyító hatásainak felhasználására vonatkozóan Ottfried Foelster 1904-es előadása hozta meg, aki egy orvosgyülésen beszélt a lóháton történő szenzomotoros kezelés hatékonyságáról (Bozori, 2002).

Napjainkban a lovak leginkább szabadidős társként, sporttársként vannak jelen az életünkben. A közlekedésben, hadászatban, mezőgazdasági munkálatokban már gépek helyettesítik az erejüket. A gyógyításban, segítő, fejlesztő területeken tett szolgálatuk lehetőségei és jelentősége azonban most kezd igazán kifejlődni, egyre fontosabbá, egyre megbecsültebbé válni. Vizsgálatok folynak a lovaglásnak az emberi test élettani folyamataira gyakorolt hatásairól (Ölsböck, 1996). Ahhoz, hogy ezeket az újabb fontos kapcsolódási pontokat ember és ló között világosan megérthessük, nem elhanyagolható a lovak legjellemzőbb személyiségbeli és viselkedésbeli tulajdonságainak bemutatása.

A lovak etológiailag három olyan releváns tulajdonsággal rendelkeznek, melyeket jelenkori, meglehetősen humanizált életterükben is szilárdan őriznek. Eszerint: a ló legelő állat, csordaállat és menekülő állat. Mint legelő állat folyamatos táplálékfelvételt igényel: valamikor csak a fü szolgálta a táplálékát, amelyből a testméretéhez és testtömegéhez viszonyított szükségleteinek megfelelő mennyiséget csak sok munkával, hosszú idő alatt tudta magához venni, egyszerre mindig csak keveset. Gyomra anatómiailag alkalmazkodott ezekhez a táplálkozási szokásokhoz: kicsi. A ló tehát egész nap eszik. Fajtájára jellemzően csordában (ménesben) élö állat, azaz a társaság a természetes közege. A lovak csak egymás társaságában érzik jól magukat. Valamikor egyedül így volt esélyük a ragadozókkal szemben az életben maradásra. A ménesben hierarchia uralkodik. A vezéregyéniségek megküzdenek vezető pozíciójukért, ám a küzdelem eredményét egyöntetüen elfogadják és tiszteletben tartják. Mindenki békével viseli a saját pozícióját társai között. Az egyedek közötti kommunikáció folyamatos: elsődleges kommunikációs csatornájuk a testnyelv, az érintés. E ménesösztönöknek köszönhetően a lovak az embert is olyannak ismerik, akivel kapcsolatot tudnak teremteni. Egyenrangúnak, felettük vagy alattuk állónak fogadnak el bennünket, avagy ellenségként tartanak számon (Hartje, 2009). Végül pedig tudomásul kell vennünk, hogy a lovak történelmileg zsákmányállatok. Mint zsákmányállat, a ló tehát menekülö állat. Alapvetően nem agresszív, a veszélytől inkább távol tartja magát. Szélsőséges helyzetben az első reakciója a menekülés. Amennyiben sarokba szorítják, úgy védekezik, ahogy tud: leginkább rúg és harap. Lovaglás során azért bakol, hogy levesse a lovast a hátáról - ahogy annakidején, valamikor az ősidőkben a hátára vetődő ragadozó állattal is tette. Az ember pedig ragadozó - ez a tény érdekessé teszi az ember-ló egyébként ösbizalmon alapuló kapcsolatát. 


\section{Az ember-ló kapcsolat}

Közös életterünkben különböző kötődésfajták alakultak ki az ember és a ló között. Manapság a lovak fizikai adottságai mellett azonban egyre nagyobb jelentőséget tulajdonítunk finomabb, avagy belső tulajdonságaiknak. Számtalan élethelyzetben (munkában, sportban, segítő kapcsolatban, orvostudományban, terápiákban...) a lovak ezen tulajdonságai kiegyenlítik az ember gyengeségeit, vagy éppen kiegészítik erösségeinket. Különleges bánásmód ez amelyben négylábú, patás társaink részesítenek bennünket elsődlegesen. Látszólag rejtélyes érzékelö képességekkel rendelkeznek, aminek valójában az az oka, hogy érzékszerveik egyes müködései sokkal kifinomultabbak, mint az emberé. A lovak olyan tartományokban is hallanak, amelyben az emberek nem. Látásuk rosszabb ugyan a miénknél, ám a legcsekélyebb mozgásváltozást is érzékelik, továbbá sötétben is látnak. Szaglásuk olyan fejlett, mint a kutyáké. Tapintási érzékelésük egész testfelületükön annyira kifinomult, hogy még a szőrükkel is érzékelnek. Fülünk helyett fülünk, szemünk helyett szemünk, orrunk helyett orrunk lehet társunk, a ló. Ismertetőnkben lassan eljutunk majd oda is, amikor lábunk helyett az ő lába lesz a mi lábunk... A lovaknak hihetetlenül gyors a reakcióidejük. Sokszor tehát hamarabb megijednek egy-egy váratlan esemény érzékelésétől, mint mi azt egyáltalán észrevennénk. Ugyanakkor szerencsére könnyen és gyorsan megnyugtathatók. Ebben a szerencsében nekünk, embereknek nem mindig van részünk... A lovak azonban fejlődéstörténetükből, zsigereikből hozzák magukkal ezt a tulajdonságukat. Ha nem lennének képesek hamar megnyugodni egy-egy veszélyesnek tűnő helyzet után, mint zsákmányállatok az egész életüket eszeveszett rohangálásban tölthetnék. A ló a leggyorsabban tanuló háziállat. Kiváló a memóriája, ez azonban egyben azt is jelenti, hogy sosem felejt. Sosem felejt, de szerencsére megbocsátó. Ha nem így lenne, megkérdőjelezhetővé válna a segítő munkában betöltött szerepük, alkalmasságuk. A ló tehát megjegyez minket, életreszólóan memorizálja közös történeteinket - és megbocsát. Elfogadja a rangsorbeli helyét és irányítható.

„A lóban megtestesülő (...) személyiségbeli jellemzők azonosak az emberben megtestesültekkel. (...) Talán a lovak megértése iránti vágyunk nem is más, mint magunk és környezetünk megértésének szándéka" (Miller, 2012, 12).

A fentiekben arról volt szó, hogy elsődlegesen maguk a lovak részesítenek bennünket, embereket különleges bánásmódban. Teszik ezt direkt vagy áttételesen, mintegy tükröt tartva elénk. Tudatos munkával is bevonhatjuk azonban életünkbe a lovak által szolgáltatott különleges bánásmódot. Ilyenkor lép közbe a gondolkodó ember, aki közvetít: közvetít a ló és egy másik ember között. Különlegesen. Az emberek ugyanis saját maguk és a lovak között azonosságokat találnak. Carl Klüver (1994) egy, különböző szakterületek szakembereiböl álló csoporttal együttműködve a testfelépítést és az élettani folyamatokat érintő hasonlóságokat tanulmányozzák, és anatómiai hasonlóságok, viselkedési formák, az észlelés és az érzékszervekre ható ingerek észlelése, valamint egy kommunikációs modell között keresnek kapcsolatot (Hartje, 2012). Eredményeik eddig alátámasztják, hogy közös tulajdonságaink a segítö, terápiás kapcsolat hasznára válnak.

\section{A ló-asszisztált különleges bánásmód intézményi háttere, megvalósulási formái}

A továbbiakban olyan lovakkal végzett foglalkozásokat mutatunk be, amelyek célcsoportját a gyermekek képezik (3-tól 14 éves korig). 
Legáltalánosabban a lovardákat, lovasiskolákat keresik fel a szülők gyermekük szabadidős vagy sportolási célú lovaglási vágya, szándéka kielégítése kapcsán.

Lovasterápiás szakirodalmak egyértelmúen bizonyítják (vö. pl. Bozori, 2002; Györgypál, 2006), hogy 3 éves életkor előtt nem szerencsés a gyermekek lóra ültetése, sőt, kifejezetten káros lehet a csípőtájéki csontozat fejlődésére nézve. Nagyon gondos mérlegeléssel terápiás céllal lóra ültethetök a kb. 2,5 éves gyermekek akkor, ha a cél a járás beindításának elösegítése, esetleg a beszédindítás - ennek módjait, körülményeit mindenképpen lovasterapeuta szakember határozza meg. Természetesen csecsemőkkel és kisgyermekekkel is ki lehet látogatni a lovardákba. Ebben az életkorban még nincs félelemérzet a gyerekekben, későbbi életükre nézve előnnyé válhat az állatokkal való korai megbarátkozás. Sokféle ingerrel találkozhatnak a lovas környezetben, ami testi-lelki-mentális fejlödésükre igen támogató, jótékony hatással lehet. Lehetőség van továbbá a kicsikkel a lovaskocsizásra természetesen tapasztalt hajtóval, megbízható körülményekkel. A fogathajtás talán kevésbé felkapott szabadidős és sporttevékenység. Ennek az lehet az egyik legfőbb oka, hogy rendkívül költségigényes. Általában nem egy, hanem több ló tartását és foglalkoztatását igényli, valamint a kocsi és az egyéb szerszámok megvásárlása és karbantartása is igen sokba kerül.

Nagyjából 9-10 éves korra elérik a gyermekek testi, lelki és szellemi fejlődésükben is azt a szintet, amikor már komolyabban elkezdhetnek lovagolni tanulni. A korábbi éveikben (3-4 éves kortól) is ismerkedhetnek már a lovaglás alapjaival, de nagyon fontos, hogy a ló méretét a lovaséhoz igazítsuk (kezdetben tehát leginkább a pónilovaglás ajánlott). A kisebb gyermekek megtanulják a lovardában a ló körüli teendöket: az ápolási, gondozási, etetési ismereteket, a felszerelések használatát. Már ezek által az ismeretek által is megkezdődik a rendhez, a szabályokhoz történő szoktatás. A lovak világához ugyanis magatartásunkkal, viselkedésünkkel is idomulnunk kell. Ez a tanulási folyamat természetesen később sem ér véget, hanem inkább életünk részévé, szinte vérünkké válik.

A gyerekek a lovakkal való első találkozásuktól fogva természetes módon sajátítanak el olyan fontos etikai szabályokat, amelyek a mindennapi életükben is elörevivő, nemes erényekként támogathatják az életüket. Ilyen erények pl. a kötelesség, a felelösség, a segítőkészség, a becsület, az önuralom és az önfegyelem, a pontosság, a figyelem és az empátia (Pongrácz, 2006). Mindazok, akik szabadidős vagy sportolási céllal rendszeresen járnak egy lovardába, ezeket a tulajdonságokat szinte észrevétlenül teszik magukévá. Attól különleges ez a bánásmód, hogy egyrészt észrevétlen tanulási folyamat, nem kell hozzá kellemetlen, nehéz erőfeszítéseket tenni (mint az iskolapadban), mintegy maguktól szívódik a gyermekekbe ez a sokfajta érték - majdhogynem azt lehet mondani: vágynak rá, hogy a magukévá tegyék őket, hogy a lovak világának ezáltal (is) mielöbb részeseivé válhassanak. Másrészt pedig nem is elsősorban emberi tényező közvetíti feléjük ezeket a tartalmakat (akikkel kapcsolatban talán inkább negatív előfeltevések élnek bennük, ami gyakran a tekintélyszemélyek szimbolikájából adódik), hanem egy, bár ugyancsak tiszteletet parancsoló, mégis meghódítani vágyott, vonzó, nemes, szeretetreméltó állati élölény. A ló a maga lényével, létezésével, személyiségével a legnagyobb motiváló erő.

Nagyon fontos például a pontosság betartása. A ló nem várhat: biológiai órája egyértelmủen jelzi az etetési időket, a munka- és pihenőfázisok közötti különbséget. Felelősséggel tartozunk érte. Szükségleteinek kielégítése rajtunk, embereken múlik - gondoskodással tartozunk neki, 
hiszen cserébe szó szerint a terhünket hordja. Megtiszteljük hát azzal is, hogy időben érkezünk a lovas foglalkozásokra, hiszen barátunk vár bennünket. Továbbá más gyerekek is sorban állnak nála - ha elkések a foglalkozásról, magammal szúrok ki, nekem marad kevesebb időm a kedvtelésemre. Amennyiben tehát valóban szívből, szeretetből járok lovagolni, nem kések el. A gyerekek önuralmat és önfegyelmet is gyakorolnak a lovardai közegben. Nem kiabálunk, rohangálunk a lovak körül, nehogy megijesszük öket. Tudjuk jól, ha éppen mi ülünk a hátukon és valaki más kezd el körülöttünk ricsajozni, rendetlenkedni, magunk sem örülünk neki, hiszen nem szeretnénk, ha paripánk ijedt reakciója miatt lerepülnénk a hátáról. Ez mindjárt az empatikus készségünk fejlődését is elősegíti. A korábbi fejezetek ismertetéséből tudjuk: a ló természeténél fogva félénk állat, a hirtelen hangokra, mozdulatokra, veszélyesnek tünő helyzetekre elsősorban meneküléssel reagál. Ez jelenthet elvágtázást vagy bakolást, amit különösen kezdő lovasok esetében nehéz uralni. Bizony: meg kell tanulni nemcsak önmagunkat, hanem lovunkat is uralni. A ló hátán ülve rövid időtartamokon belül is nagyon sok mindenre kell egyszerre figyelni. Így a lovaglás fejleszti a koncentráló képességünket. Az itt felsoroltakon kívül még számos olyan fontos viselkedési szabállyal van módunk megismerkedni a lovaséletben, amelyek a lovardán kívüli életünkben is hasznunkra válnak. Ide tartoznak olyan udvariassági szabályok, mint a köszönés érkezéskor és távozáskor, a pályára vagy fedeles lovardába történő belépéskor a „Helyet kérek!" engedélykérö formula alkalmazása, öltözködési irányelvek, amelyek betartása magunk és mások testi épségének, biztonságának betartását is szolgálják, s az előzékenység gyakorlása: előbb a lovam szükségleteit elégítem ki, azután a magamét (bármilyen éhes vagy szomjas is vagyok, elöbb a lovamat látom el, azután következem én).

Nagyobb gyermekek, akik már az általános iskola felső tagozatába (különösen 7-8. osztályba) járnak, megfelelö alapismeretekkel, rendszeres és tudatos edzésprogrammal, szakképzett lovasoktató, illetőleg lovasedző segítségével a versenysportba is bekapcsolódhatnak. A fentiekben ismertetett lovas foglalkozások, lovaglástanulás vezetéséhez a mai magyar jogszabályi rendelkezéseknek megfelelően lovasoktató, esetleg lovastúra-vezető végzettség is megfelelő, azonban a versenyzésre való felkészítéshez, valamint a versenypályára történő belépéshez már lovasedzői végzettséget írnak elö (asszisztenciaként - Net1). A versenysportok közül a díjlovaglás, díjugratás és military szakágak választása a legnépszerübb, ezek közül is az első helyen talán a díjugratás áll. A tapasztalatok szerint azoknak a gyerekeknek a személyisége, akik korán kezdik a lovassportot, a versenyzést, hamarabb érik, mint kortársaiké. Személyiségfejlődésük sokkal könnyebben rátalál egy olyan kívánatos személyiségstruktúrát feltételező útra, amely egyrészt felelősségteljes életvezetést eredményez, másrészt kedvezően hat az emberek közötti kapcsolatokra (Berentés, 2012). Fiatal koruk ellenére nagyon felelősségteljes munkát végeznek. Pontos, fegyelmezett együttmüködést kell megvalósítaniuk egy 600-700 kg-os, önállóan ,gondolkodó” élölénnyel, valamint az edzőjükkel. Az eredményesség csak ebben a partneri viszonyban, partnerként való gondolkodásmódban valósulhat meg közöttük. (Ennek hiányában komoly veszélyeknek, fizikai sérüléseknek teszik ki magukat. Ellenben az együttmüködő magatartás megvalósulásának köszönhető sikerek láttán komoly önértékelést növelö, igazán felemelő érzésekben lehet részünk.) Mindhárom említett sportágban széles körü és tartós figyelemre, gyors helyzetfelismerésre van szükség, gyors reagálásra, ami csak az egész személyiség erőinek mozgósításával érhető el. Milyen személyiségtulajdonságok edződnek tehát ebben az edző-ló- 
lovas viszonyban? A versenyző megtanulja, hogy a türelmetlenség, valamint a düh és a méreg csak megfélemlíti a lovat: menekülésre vagy önvédelmi magatartásra ösztönzi. Ha viselkedésünket képesek vagyunk kontroll alatt tartani, jelentősen javíthatjuk az emberek közötti kommunikációs, megértő és beleérző képességünket is (Miller, 2012). A sportoló hamar megtanulhatja, hogy a lónál az erőszak ellenkezést, a bizalmaskodás tiszteletlenséget szül. A ló felé vezető leghatékonyabb út a szeretet és az irányítás. Aki mindezt a lovasedzéseken és a versenypályán gyakorolja, annak azt sem kell külön megtanítani, hogy az emberi kapcsolataiban is tovább jut meggyőzéssel, mint erőszakkal. A lovak esetében a meggyőzés fontos eleme a jutalmazás. A jutalmazásnak, dicséretnek azonnalinak kell lennie. Csak igen szélsőséges esetekben szabad büntetni, ellenben minden apró kis eredményt dicsérni kell (simogatással, jó szóval: pl. „Jól van!”). A jó edző lovasával is úgy bánik, mint lovával: a legkisebb eredményt is észreveszi és méltatja, dicséretből szaporábban juttat, mint elmarasztalásból. A rendszert átfogja a legfőbb szabály: a következetesség. Eredményesség ugyanis csak ezen az úton, következetes magatartással érhető el.

Dallos Gyula, neves magyar díjlovas és edző, többszörös világkupa-helyezett, örökös magyar bajnok szavai híven tükrözik az eddig elmondottakat: „A lovaglás egyfajta magatartásforma is, hiszen a ló megtanítja az embert viselkedni (Net2)”.

\section{A ló-asszisztált különleges bánásmód megjelenése lovasterápiás foglalkozásokon}

Az előző fejezetből szándékosan maradt ki egy intézményi háttér bemutatása. Erre ugyanis itt külön szeretnénk kitérni: a lovasterápia infrastrukturális és személyi feltételeinek, megvalósulási formáinak, müködésmódjának, eredményességének ismertetésére.

A lovasterápia a ló, a lovaglás és a lóval való foglalkozások hatásait felhasználó komplex eljárás, amelynek mozgásfejlesztő, gyógypedagógiai és pszichológiai vonatkozásai vannak (Bozori, 2002; Györgypál, 2006). Azoknak a gyerekeknek, fiataloknak és felnőtteknek teremt különleges kiegészítő terápiás lehetőséget, akik valamilyen mozgásszervi, érzékszervi, mentális, nyelvi-/beszéd- vagy szociális, pszichés problémával élnek. Lovasterápiás keretek között olyan szakemberek foglalkoznak velük, akik gyógytornász, gyógypedagógus, pszichológus, pszichoterapeuta vagy orvos alapdiplomával rendelkeznek és erre építve elvégezték a Magyar Lovasterápia Szövetség által akkreditáltatott lovasterapeutatovábbképzést. A gyógytornász-lovasterapeutákat összefoglaló néven hippoterapeutáknak nevezzük, míg a gyógypedagógiai és a pszichológiai szakág képviselőinek titulusát a szükebb értelemben vett lovasterapeuta fogalom jelöli (hozzátéve, hogy gyógypedagógiai lovaglás és voltizsálás, vagy pedig ló-asszisztát pszichoterápia szakágon). A lovasterapeuták (innentől tágan értelmezve, mindhárom szakág képviselőire használva a kifejezést) hazánkban többnyire alapítványi keretek között vagy magánúton (egyéni vállalkozóként) dolgoznak, saját lovardában vagy egyéb, már müködő lovardához csatlakozva. A lovasterápiás ellátást az Egészségpénztárak egyelöre Magyarországon még nem finanszírozzák.

A lovasterápiás megsegítés neuropszichológiai alapja, hogy a páciensek szenzomotoros müködését ösztönözzük, amit a ló előrehaladó lépő mozgása biztosít. Ennek számtalan pozitív vonatkozása van: 
- A lépő ló által keltett mozgásimpulzusokat a ló hátán ülő páciens medencéje átveszi, a gerincoszlop hullámszerüen továbbítja a nyakszirtig, végül a nagyagykérgi központokig.

- A tartós mozgásimpulzus az egyensúlyozásért felelős szerveket szenzomotoros tanulásra ösztönzi. A ló háromdimenziós, ritmikus mozgása olyan gazdag ingereket nyújt, mint amilyeneket a magzat az anyaméhben érzékelt. Amennyiben egy gyermeknél koraszülés következtében ezeknek az érzéki tapasztalatoknak a folyamata megszakadt, a lovasterápia azokat pótolhatja, helyettesítheti. Fejleszti az idegösszeköttetéseket, vagy akár új idegsejtmüködéseket is beindíthat (Dr. Büki, 2006), amelyek a mozgás folyamatát támogatják, ezáltal fejlesztően hatnak a koordinációra, a mozgásminták elsajátítására, rögzítésére.

- A lovasterápiát szokás járástipikus törzstréningnek is nevezni (Györgypál, 2006a; Katona, 2006). Amennyiben a gyermek járása koordinálatlan, mert pl. a kisagyban hiányoznak a megfelelő ideg-összeköttetések, akkor a lépésben járó ló mozgása lengési mintát és idegi impulzust ad a rajta ülő páciensnek a járásról (Hartje, 2012). Mindebben az a nagyszerü és különleges, hogy a pácienstől tulajdonképpen semi-lyen határozott erőfeszítést nem igényel, ellentétben a sokszor nagyon fájdalmas gyógytorna-beavatkozásokkal.

- A lépésben haladó ló a hátán ülő páciens összes izmát megmozgatja, ahol kell, ellazít, másutt megerősít. Motivál az egyensúlyra, a szimmetrikus ülésre. Képes az abnormális mozgások korrekciójára és a helyes mozgások automatizálására.

- Javítja a keringést, a légzést és az anyagcserét.

- Hatékony lehetőséget biztosít a kognitív funkciók (érzékelés, észlelés, emlékezet, figyelem, gondolkodás) fejlesztésére, a nonverbális és verbális kommunikáció javítására, a motoros és orientációs képességek, az érzelmi állapot, az akarati, cselekvési képességek befolyásolására. Miközben a hintázó mozgásimpulzusok pozitívan hatnak az agyféltekék közötti információcserére, a lovasterapeuta felhívhatja a gyermek figyelmét arra, hogy pl. hová néz a ló, vajon mit figyel éppen - észrevétlen lehetőséget teremtve ezzel az észlelési folyamatok fejlesztésére.

- A fizikai görcsök feloldása pedig lelki oldódást is eredményez: a lovon ülő beteg számára kinyílik a világ, ő maga is kezdeményezőbbé, kommunikatívabbá válik.

A terápiás ló azon kívül, hogy mozgásmintát szolgáltat és a mozgásimpulzusokon keresztuil észrevétlenül gyógyítja a fizikumot, különféle szociális viselkedésmintákat is közvetít, amelyen keresztül a páciensek felismerhetik saját kedélyállapotukat, hangulatukat, ezzel elősegítve a társas kapcsolataik alakulását, fejlődését. Úgy is fogalmazhatunk, hogy a 
szenzomotorikus gyakorlatok arra késztetik a testet, hogy érzékelje saját magát, a szocio- és pszichomotorikus gyakorlatok pedig elösegítik a kapcsolatok létesítését és az érzelmek közlését (Hartje, 2012).

A lovasterápiának az érzelmek felismerésére és kifejezésére, a társadalmi beilleszkedés elősegítésére gyakorolt hatását jól illusztrálja a következő esetbemutatás. Egy 14 éves (dadogással kapcsolatos problémájával érkezett) fiú személyiségének tartott éles tükröt egy alkalommal a terápiás lovunk. A fiú karakterére, viselkedésére jellemző, hogy szeret irányítani, ezzel párhuzamosan nem hajlandó elfogadni mások vezetését, befolyását, akaratát. Ez a merev ellenkezése kiterjed az iskolai közegre, a tanárokra, tekintélyszemélyekre, valamint a szüleire is. (Felmerül a kérdés, hogy vajon görcsös dadogása és ugyancsak „görcsös”, merev, ellenálló viselkedése között lehet-e kapcsolat...) Az adott foglalkozáson a ló önálló irányítását gyakoroltuk (a szárfogás elsajátításával párhuzamosan), a foglalkozás végén a földről vezette kantárszáron a lovat, majd az istállónál is ő vette le a fejéről a kantárt és cserélte azt kötőfékre, végül vezette boxába a lovat. A ló nem nagyon volt készséges, együttmüködő. Nagyon lustán lépett, próbált kitérni az irányváltoztatások elöl. Amikor már a boxa előtt állt, türelmetlenül várta a bebocsátást, hiszen a vacsoraideje már rég elérkezett, odabent várta az abrak. Ez a belső türelmetlensége külsődlegesen abban nyilvánult meg, hogy fejével a kantár levételekor nyugtalan mozdulatokat tett. Ekkor páciensünk is hirtelen ingerült lett, amit mind nonverbálisan, mind verbálisan kifejezett. Arra a kérdésre, hogy mit érez az adott pillanatban, illetőleg mit tenne, azt válaszolta, hogy legszívesebben jól odacsapna a lónak, de természetesen nem teszi és visszafogja magát. Mert nem azt csinálja, amit ő akar... Mindjárt párhuzamot vontunk saját iskolai viselkedésével és beszélgettünk arról, hogy tanárai, illetőleg szülei mit érezhetnek olyankor, amikor ő ellenkezik ilyen hevesen. Nagyon erős tapasztalati élmények lehetnek ezek!

Hasonló módon tanította folyamatosan a szociális interakciókra terápiás lovunk azt a 8 éves autizmus spektrumzavarral diagnosztizált kisfiút, akinek erősen inadekvát kommunikációját igyekeztünk adekváttá tenni. Nyári időszakban elég sok a légy, a lovak pedig nagyon finoman érzékelnek (a tanulmány korábbi részéböl kiderül, hogy nemcsak a börükkel, hanem a szőrükkel is). A kellemetlen csípések ellen nincs más módjuk védekezni, minthogy a farkukkal legyezik magukat, olykor a lábaikkal dobbantanak, esetleg sörényüket (nyakukat) megrázzák. Miközben a páciens a lovon ül, s a ló a farkával legyezi a bogarakat, gyakran a pácienst is éri a faroklegyintés. A kisfiú lassanként megtanult önállóan rászólni a lóra, adekvátan, verbálisan kinyilvánítani érzéseit, gondolatait: felszólította, hogy „Ezt hagyd abba!”, „Fejezd be, Pazar!” Megtanulta a különféle cselekvéseket és történéseket szóban kifejezni. Pl. amikor a ló megvakarta a szájával az oldalát, épp a gyermek lába mellett, akkor azt a kisfiú türelmesen kivárta, majd közölte, hogy „,Megviszketett neki.” Amikor a ló prüszkölt, a gyermek reflektált rá: „Egészségedre!” Többéves közös munka után nagy örömünkre az is elöfordult, hogy a lovaglás végén a lovat megdicsérve, megsimogatva átkarolta a nyakát és azt mondta neki: ,Szeretlek!'.

Miközben a páciens hagyja, hogy a ló a hátán vigye őt, megtapasztalja az ősbizalom érzetét - hiszen a terápiás ló vigyáz rá, mert megérzi, ki az, aki gyenge és sebezhető, s az ilyen emberrel pontosan úgy viselkedik, mint a ménesben a védelemre szoruló kiscsikóval (Hartje, 2012). Súlyos ADHD-val diagnosztizált 6 éves kislánnyal, illetőleg egy mozgáskoordinációs nehézségekkel küzdő 7 éves kisfiúval fordult elö, hogy futószáron történő ügetés során 
kibillentek a gyerekek az egyensúlyukból. De még mielőtt leeshettek volna a lóról, a ló abban a pillanatban kiegyensúlyozta az ő elmozdulásukat: ,alájuk” lépett, majd azonnal megállt. Nem történt baleset, negatív élmény, sőt, a gyerekek bizalma megerősödhetett a terápiás ló iránt.

\section{Összegzés}

A ló-asszisztált foglalkozásoknak nem a teljes spektrumát, de azokat a körvonalait igyekeztünk bemutatni, amelyekkel a 3-14 éves korosztályba tartozó gyerekek leggyakrabban találkoznak, érintkeznek. Ezeken a foglalkozásokon vagy „csupán” a lovak, vagy pedig a lovasoktatók, edzők, illetőleg lovasterapeuták személye kapcsán lehet részük megtapasztalni a különleges bánásmódot. Ez a bánásmód attól különleges, hogy nem igényel tőlük olyasfajta kötelezettségérzettel járó, „,nemszeretem”-típusú tudatos aktivitást, mint egy iskolai feladat, egy különóra, legyen az tehetséggondozás vagy korrepetálás, illetőleg egyéb terápiás/fejlesztő foglalkozás vagy netán gyógykezelés. A lovak iránti vonzódás, a lovak szeretete az, amely természetes módon szólítja meg öket. Olyan közegben, amely távol áll a hivatalos intézmények bezárt, komor falaitól, mert kint van a szabadban, a jó levegőn, a természetben. A lovak mozgása és személyisége által pedig még azok is észrevétlenül gyógyulhatnak vagy fejlödhetnek, akik tulajdonképpen nem is tesznek ezért különösebb konkrét lépéseket - a ló ugyanis olyan tanító és gyógyító, aki elvégzi helyettünk a munka „oroszlánrészét”, nekünk pedig nincs más dolgunk, mint örömmel elfogadni a tőle kapottakat.

\section{Irodalom}

Berentés, É. (2012). Az érett személyiség. Budapest: Pro Personal Kiadó.

Bodó, I. \& Hecker, W. (2013). Lótenyésztés, lótartás, lóhasználat. Budapest: Mezőgazda Kiadó.

Bozori G. (2002). Lovasterápia. Gondolatok és vázlatok a gyógypedagógiai lovaglás és lovastorna témaköréből. Székesfehérvár: Polu-Press Kkt.

Büki, Gy. (2006). A hippoterápia neurofiziológiai alapjai. In Györgypál Zoltánné (szerk.): Hippoterápia. Balogunyom, Unicornis Egészségforrás Alapítvány. 36-62.

Györgypál Zoltánné (szerk.) (2006). Hippoterápia. Balogunyom: Unicornis Egészségforrás Alapítvány.

Györgypál Zoltánné (2006a). A hippoterápia. In Györgypál Zoltánné (szerk.): Hippoterápia. Balogunyom, Unicornis Egészségforrás Alapítvány. 14-18.

Hartje, W. (2009). Lovasterápia. Budapest: Mezőgazda Kiadó.

Katona, E. (2006). A ló mozgásának elemzése, hatása a páciensre. In Györgypál Zoltánné (szerk.), Hippoterápia. Balogunyom, Unicornis Egészségforrás Alapítvány. 28-35.

Klüwer, C. (1994). Der Bereich des Heilpädagogischen Voltigierens/Reitens im Gesamtgebiet des Therapeutischen Reitens. In Gäng, M. (szerk.), Heilpädagogischen Reiten und Voltigieren. München, Basel, Ernst Reinhardt. 18-22.

Miller, M. (2012). Értsük meg a ló viselkedését! Budapest: Mezőgazda Kiadó.

Net1: 14/2008. (XII. 20.) ÖM rendelet a lovas szolgáltató tevékenységröl. Letöltés: 2015. 10. 10. Web: http://net.jogtar.hu/jr/gen/hjegy_doc.cgi?docid=A0800014.ONM 
Net2: Lovak között boldogan - Dallos Gyula. Letöltés: 2015. 10. 10. Web: http://www.lovasok.hu/index.php?i=17369

Novotni, P. (2007). Lovak testközelben. Budapest: Aquila Könyvkiadó.

Ölsböck, L. (1996). Wertigkeit der Hippotherapie in der Behandlung cerebralparetischer und mehrfach behinderter Kinder. DKThR. Sonderheft Hippotherapie.

Pongrácz, L. (2006). A mesterlovász könyve. Budapest: Szaktudás Kiadó Ház Rt. 